\title{
A viagem de José Gonçalves da Fonseca e a cartografia do rio Madeira (1749-1752)'
}

\begin{abstract}
André Ferrand de Almeida ${ }^{2}$
RESUMO: Este artigo analisa a viagem da "real escolta", uma expedição de reconhecimento enviada de Belém do Pará, em 1749, para explorar a comunicação fluvial entre o Estado do Maranhão e Grão-Pará e o Mato Grosso através da rota formada pelos rios Madeira, Mamoré e Guaporé, e seu impacto na cartografia deste espaço. As grandes diferenças entre - mapa traçado por José Gonçalves da Fonseca e o Mapa das Cortes criaram grande perplexidade aos responsáveis políticos portugueses antes de darem início às demarcações de limites acordadas com a coroa espanhola no Tratado de Madri de 1750.

PAlAVRAS-ChAVE: Mapas. Fronteiras. Rota fluvial. Mato Grosso. Rio Madeira. Tratado de Madri.
\end{abstract}

ABSTRACT: This article looks into the voyage of the "royal escort", a reconnaissance expedition sent from Belém do Pará in 1749 to explore the fluvial communication between the state of Maranhão and Grão-Pará and the captaincy of Mato Grosso down the courses of the Rivers Madeira, Mamoré and Guaporé, and its impact on the cartographic representation of this region. The considerable differences between the map drawn by José Gonçalves da Fonseca and the map of the boundaries of Brazil prepared for the negotiations with the Spanish Crown astonished the Portuguese politicians in charge of the matter before they set out to demarcate the South American territories according to the Treaty of Madrid signed by Portugal and Spain in 1750.

KEYWORDS: Maps. Boundaries. River courses. Mato Grosso. Madeira River. Treaty of Madrid.

A abertura da estrada fluvial pelos rios Guaporé, Mamoré e Madeira

Em setembro de 1748, o secretário de Estado Marco António de Azevedo Coutinho ordenava a Francisco Pedro de Mendonça Gorião, governador do Estado do Maranhão e Grão-Pará, que organizasse uma expedição de
1. Uma versão inicial deste texto foi apresentada no $\mathrm{V}$ Simpósio de História Marítima e Naval Ibero-americana Rio de Janeiro, 25 a 29 de outubro de 1999.

2. Centro de Estudos Geográficos da Universidade de Lisboa. Doutorando em História e Civilização no Instituto Universitário Europeu, em Florença. Mestre em História dos Descobrimentos e da Expansão Portuguesa pela Universidade Nova de Lisboa, tem-se dedicado à História do Brasil no período colonial, em particular à História da Cartografia. É colaborador regular da Área de Cartografia da Biblioteca Nacional de Lisboa desde 1998 E-mail: <andreferrand@gmail. com>. 
3. Cf. Marco Antonio de Azevedo Coutinho (1987, p. 47).

4. Idem, p. 46.

5. Sobre a expedição de Palheta, cf. C. de Abreu (1982, p. 305-316).

6. Cf. Ofício de Francisco Pedro de Mendonça Gorjão, governador do Estado do Maranhão, enviado a 3 de novembro de 1747 ao Cardeal da Mota (Arquivo Histórico do Itamaraty, Arquivo Barão Duarte da Ponte Ribeiro, Lata 288 , maço 8 ). O mapa do rio Madeira mede $40 \mathrm{x}$ $30 \mathrm{~cm}$ e encontra-se na $\mathrm{Ma}$ poteca do Itamaraty (Rio de Janeiro). Tem uma longa legenda com a descrição do rio, a localização das missões espanholas de Moxos junto do rio Mamoré, das missões dos jesuítas portugueses no alto Madeira e a narração da viagem de Palheta. Cf. I. Adonias (v. 1, 1960, p. 63-64; 1993, p. 94) reconhecimento do rio Madeira. Temia-se a expansão das missões de Moxos, pertencentes à Província do Peru, da Companhia de Jesus, para oeste do eixo fluvial formado pelos rios Madeira, Mamoré e Guaporé, receio esse que a fundação, em 1743, da missão de Santa Rosa, na margem oriental do rio Guaporé, viera agravar. Podia estar em causa o controle da navegação daquela rota fluvial, que permitia a comunicação do Mato-Grosso com o Pará, até então proibida pela coroa portuguesa, por recear o despovoamento das regiões mineiras de Cuiabá e do Mato Grosso e para evitar o contrabando do ouro. Mas a principal preocupação era de que os índios da nova aldeia de Santa Rosa descobrissem ouro em suas proximidades e que isso pudesse atrair outros moradores, nomeadamente espanhóis vindos das regiões de Chuquisaca e de Potosi, o que complicaria ainda mais a disputa acerca da rota fluvial do Madeira:

Suposto o que deixo explicado tem-se por necessario, e conveniente, naõ sô apossarmo-nos da navegaçaõ do Rio da Madeira athê o Mato grosso, maz tomar a tempo as medidas para que a dita nova Missaõ Espanholla noz naõ cauze os prejuizos, que podemos recear, ou procurando os meyos para a tirar daly, sem escandalo, ou rodeando-a em alguma distancia com abitaçoens, e sesmarias dos nossos, de sorte que se naõ possaõ os Castelhanos alargar, nem tentar outros estabelecimentos da parte oriental do Rio da Madeira, e talvez virâ a ser conveniente para este effeito permeti-se, e frequentar-se a comunicaçaõ do Parâ com o Mato groço por aquelle $\mathrm{Rio}^{3}$.

Azevedo Coutinho lamentava-se, também, da pouca informação existente acerca do baixo Madeira, precisamente a parte do rio onde se encontravam estabelecidas missões dos jesuítas portugueses:

Este Rio da Madeira hê pára nós hoje mais conhecido da parte de cima e athe às Missões dos Moxos, do que da parte de baixo, sem embargo de ser nesta parte occupado com Missoens dos nossos Jesuitas do Parâ; porem athê agora naõ houve a curiozidade de se remeter, nem Mapa, nem relaçam disso mesmo, que ocupamos, e muito menos, do que fica para cima. Sabe-se comtudo que ja algumas vezes foram Portuguezes do Rio das Amazonas, com canoas de voga, e saveiros athê as Missoes dos Moxos, que he o que basta para constar que athê o Mato groço se pode navegar com a mesma comodidade; pois dos Moxos para cima nam tem embaraço algum 4 .

Não era inteiramente justo esse comentário do secretário de Estado sobre a negligência dos jesuítas portugueses, e do próprio governador do Maranhão, na recolha de informações sobre o rio Madeira. Já em 1747, José Gonçalves da Fonseca, secretário do Governo do Estado do Maranhão e Grão-Pará, desenhara um mapa do rio Madeira com base nas informações recolhidas por Francisco de Melo Palheta - que, vindo do Pará, subira o rio Madeira em 1723 - e em outros dados recolhidos junto a sertanistas e missionários $^{5}$. Este mapa foi remetido ao cardeal da Mota e a Alexandre de Gusmão, que solicitara ao governador informações mais precisas sobre o Madeira e a sua comunicação com as minas do Mato Grossob. 
De fato, durante os anos de 1747 e 1748 é patente, por parte do governo do Maranhão, o esforço de recolha e sistematização de informações não apenas sobre o rio Madeira, mas também sobre o Tapajós, por onde, vindo do Mato Grosso, o conhecido sertanista João de Souza Azevedo alcançara o Pará nesse mesmo ano ${ }^{7}$. Algumas dessas informações eram obtidas junto a sertanistas que chegavam ao Pará, é certo, muito embora os missionários, sobretudo jesuítas e carmelitas, também aqui desempenhassem um papel importante.

Contudo, Azevedo Coutinho estava certo num ponto: o conhecimento da rota do Madeira (e também a do Tapajós) ligando o Mato Grosso ao Pará ficava a dever-se essencialmente aos sertanistas vindos do Mato Grosso. Por eles se soube também dos progressos das missões dos Moxos e da fundação da nova aldeia de Santa Rosa na margem oriental do rio Guaporé. De fato, desde a expedição de Palheta - que, atravessando as suas difíceis cachoeiras, subira o rio Madeira em 1723 e alcançara a missão da Exaltação da Cruz de Cajuvava -, sabia-se da proximidade entre as missões de Moxos e as aldeias dos jesuítas portugueses no Madeira. Mas, depois dessa expedição lapesar da permanência dos jesuítas portugueses no baixo Madeira e da frequência do rio por tropas de resgate, ou com o propósito de colheita do cacau e outras "drogas do sertão"), estagnou-se a exploração do Madeira feita a partir do Maranhão, seja por iniciativa do Estado, dos colonos, ou dos missionários ${ }^{8}$. E foi graças aos sertanistas que exploraram e abriram a rota fluvial ligando os rios Guaporé, Mamoré e Madeira, à revelia da coroa portuguesa, que se tornou possível a comunicação entre o Pará e o Mato-Grosso.

No início da década de 1740, devido ao esgotamento de algumas lavras nas minas do Mato Grosso (descobertas cerca de dez anos antes), a sobrevivência dos "mineiros" foi-se tornando cada vez mais difícil. $\bigcirc$ abastecimento das regiões das minas era normalmente feito a partir dos caminhos que ligavam - Mato Grosso a Cuiabá, que, por sua vez, comunicava-se com Goiás, Rio de Janeiro e São Paulo. Mas as distâncias e as dificuldades do transporte tornavam o preço de todos os produtos, uma vez chegados ao Mato Grosso, verdadeiramente proibitivos ${ }^{9}$. É assim que se explica a constituição de um grupo de mineiros (liderados pelo reinol Manuel Félix de Lima e pelo paulista Francisco Leme do Prado) que, por se encontrarem endividados, decidiram tentar sua sorte em busca de novas lavras de ouro e das missões de Moxos, com as quais pretendiam comerciar.

Em junho de 1742, liderados por Manuel Félix de Lima, os sertanistas desceram o rio Sararé até à sua confluência com o Guaporé, no local chamado Porto da Pescaria. Aí fizeram abastecimentos e continuaram a viagem, descendo o Guaporé. Alcançaram, pouco depois, a aldeia de São Miguel, na margem do rio Baures. Aqui, os sertanistas foram recebidos por um padre jesuíta. Souberam, assim, que se tratava da mais recente aldeia das missões de Moxos, da Companhia de Jesus ${ }^{10}$. Da missão de São Miguel, seguiram para a de Santa Maria Madalena, situada no rio Ubaí ou Itonamas, outro dos afluentes do Guaporé. Dirigida pelos padres José Reiter e Atanásio Teodoro, a missão era
7. Ver, na Biblioteca Pública de Évora, as informações sobre os rios Madeira e Tapajós, correspondentes aos anos de 1747 e 1748 que constam do Códice CXV/ 2-13, fls.326-334 v. e 339342. Parecem ter sido reunidas com o propósito de compreender se seria possível utilizar um desses rios para a viagem do governador $\mathrm{D}$ António Rolim de Moura até ao Mato Grosso. Num desses documentos - que não se encontra assinado, mas que parece ser dirigido ao Rei ou ao Conselho Ultramarino pode ler-se: "Estas são as notícias que posso dar. Mas nenhumas merecem atenção afim de que por ellas se possa entrar na ideia e projecto de haver de hir o governador do Mato Grosso por algum destes dois rios. Pello da Madeira não, por não ser conveniente que hum Governador vá por hum caminho de especulação sem se saber se ha caminho das Missõens Castelhanas para o Mato Grosso, ou se haverão serras, e Pantanos insuperaveis. E taobem por não ser conveniente que hum governador Portuguez que vai ser padrasto aos Castilhanos, haja de hir por via destes, e exposto a negarem lhe o passo" (fl. 341 v.).

8. Isto mesmo confirmava o governador Mendonça Gorjão, atribuindo a decadência da exploração do rio Madeira aos ataques dos índios Mura: "No mesmo Rio da Madeyra indo por elle asima desde o Amazonas a vinte e outto dias de viagem perto da primeira cachoeyra tivemos situada hua aldea chamada Santo Antonio missionada pellos Religiosos da Companhia de Jezus a qual retiraraõ, e se fundou de novo na entrada do mesmo rio para nesta nova habitação se livrar milhor das hostelidades do Gentio Mura, que infesta aquela ribeira de hua, e outra parte. Navegavão os moradores do Pará este rio, e nas suas margens entravão à colheyta do cacao, e mais drogas do certão; porem athe a 
frequencia desta extracção se deminuhio, de sorte que raros são os homens que se animão a esta empreza por cauza de mortes, e roubos, que experimentarão do ditto Gentio". Ver Carta de 22 de Abril de 1749, Arquivo Histórico Ultramarino, Documentos Avulsos, Pará, 1750. Este documento e outros citados abaixo, nas notas 16 a 19 , estão no Arquivo Histórico Ultramarino (doravante referido como $\mathrm{AHU}$ ), sendo referenciados segundo a catalogação antiga, isto é, anterior ao Projeto Resgate.

9. Ver as cartas dos governadores Francisco Pedro de Mendonça Gorjão e Francisco Xavier de Mendonça Furtado, datadas, respectivamente, de 3 de dezembro de 1751 e de 20 de Janeiro de 1752. Apud A. C. F. Reis (v 2, 1993, p.147-150; 161 . 162).

10. Sobre a história das Missões de Moxos, ver D. Block (1994, p. 33-54); e, também, Francisco Leme do Prado (1987, p. 50).

11. Idem, p. 50-51. Ver, também, R. Southey (1981, p. 186-187).

12. Ver Auto de perguntas feitas a Manoel Felix de Lima e a Manoel de Freitas Machado, Belém do Pará, 18 de fevereiro de 1743 , no $\mathrm{AHU}$, Documentos do Pará, Cx. 25, D. 2387 .

13. Seguimos, aqui, D. Davidson (1970, p. 49-50); ver também o relato de José Barbosa de Sá (1901, p. 5-58), escrito em 1775, onde o autor se refere à sua ida às Missões de Moxos, em 1743, è à expedição anterior de Manuel Félix de Lima.

14. Ver D. Davidson (1973, p. 92).

15. Ver Francisco Leme do Prado (1987, p. 54). Trata-se do relato da segunda viagem em 1743. visivelmente rica, quer em gado, quer do ponto de vista agrícola ${ }^{1}$. Ao que parece, depois da recusa do padre Reiter em vender gado aos sertanistas, Francisco Leme do Prado, à procura de melhor sorte, partiu com alguns dos companheiros em direção à missão de Exaltação da Cruz, no rio Mamoré, onde Palheta já estivera em 1723. Na aldeia de Santa Maria Madalena, com Manuel Félix de Lima, ficaram outros sertanistas com alguns escravos negros e índios. Após esperarem em vão por notícias do grupo de Leme do Prado, retomaram a navegação do Guaporé até a junção com o rio Mamoré e continuaram depois o seu caminho descendo o rio Madeira rumo ao Parál' .

O grupo de Leme do Prado, seguindo a rota fluvial do Guaporé ao Mamoré, demorou mais de vinte dias até chegar à missão da Exaltação de Santa Cruz. Também nesta aldeia não tiveram maior sucesso em suas tentativas para comprar gado, e foram informados, pelos jesuítas, de que havia ordem do governador de Santa Cruz de la Sierra para não thes vender o que quer que fosse. Ao saberem da partida de Manuel Félix de Lima pelo rio Madeira, decidiram regressar ao Mato Grosso, refazendo em sentido contrário o trajeto que os levara até ali.

Uma vez chegados ao Mato Grosso, em janeiro de 1743, o ouvidor João Gonçalves Pereira mandou interrogar os sertanistas pelo juiz ordinário. Consciente da importância da viagem realizada, decidiu enviar de novo Francisco Leme do Prado, com José Barbosa de Sá e João dos Santos Verneque Isupostamente a serviço da Coroa), para obter mais informações sobre as missões de Moxos ${ }^{13}$. Desta vez os sertanistas foram menos bem acolhidos. Os jesuítas das missões tinham recebido ordens expressas do provincial e do governador de Santa Cruz de la Sierra de thes barrar a passagem e não os deixar sequer visitar as aldeias ${ }^{14}$. Apesar disso, ainda conseguiram voltar a visitar duas missões: Santa Maria Madalena e Exaltação da Cruz, onde foram informados pelos jesuítas que thes era interdito não apenas o comércio mas também a visita às aldeias. $\bigcirc$ mais importante desta expedição foi a observação do estabelecimento de uma nova aldeia, a missão de Santa Rosa, fundada cerca de três meses antes na margem oriental do rio Guaporé15.

Manuel Félix de Lima e os outros sertanistas, ao fim de cerca de dois meses de viagem pelo rios Guaporé, Mamoré e Madeira, alcançaram a aldeia de Santo Antônio das Cachoeiras, administrada pelos jesuítas portugueses. Passando por outras duas aldeias desses, prosseguiram a descida do rio Madeira e, ao fim de um mês, entraram no rio Amazonas. Outro tanto demoraram na navegação do Amazonas até alcançar Belém do Pará, onde chegaram em fevereiro de 1743. Chegados a Belém, João de Abreu Castelo Branco, governador do Estado do Maranhão e Grão-Pará, mandou Timóteo Pinto de Carvalho, ouvidor do Pará, interrogar os dois sertanistas que ali tinham chegado; e deu-lhes ordem de prisão por considerar que tinham violado a lei de 27 de outubro de 1733, que proibia a abertura de novos caminhos para entrar ou sair de quaisquer minas já estabelecidas. Depois de feito o auto de perguntas, enviou-os para Lisboa, presos, onde foram interrogados pelos ministros do rei. A reação do Conselho 
Ultramarino veio confirmar a proibição da comunicação entre o Mato-Grosso e o Pará, não permitindo a abertura da rota fluvial recém-descoberta ${ }^{16}$.

Aparentemente, a interdição da comunicação entre o Mato Grosso e o Pará tinha sua razão de ser. A Coroa Portuguesa temia, antes de mais nada, o contrabando do ouro, fenômeno de difícil controle com os caminhos então existentes, que, a partir do litoral, permitiam o acesso às regiões mineiras do sertão. Receava-se por outro lado, o despovoamento do Pará, já de si pouco povoado, à semelhança do que acontecera nas regiões de São Paulo, do Rio de Janeiro e da Bahia, com a migração populacional para os centros mineiros do interior ao longo da primeira metade do século XVIII. Eram estes os dois argumentos que levaram os ministros da Coroa Portuguesa, num primeiro momento, a procurar impedir a navegação dos rios ligando o Mato Grosso ao Pará. Mas as informações recolhidas pelos sertanistas do Mato Grosso - de estarem as missões de Moxos próximas dessas minas e em expansão, com a fundação da nova aldeia de Santa Rosa na margem oriental do rio Guaporé - vinham colocar a Coroa perante um dilema de difícil solução: ou autorizava a abertura da rota do Madeira e garantia a navegação desse rio (que, pelo menos desde a expedição de Palheta, ambicionava como limite oeste do território brasileirol ou corria o risco de perder uma grande parte do território das minas do Mato Grosso e mesmo de Cuiabá, frente ao aparente dinamismo das missões de Moxos. A questão era tanto mais candente quando, entre as duas cortes ibéricas, desde 1747, negociava-se um novo tratado de limites, que deveria por fim aos diferendos nunca antes solucionados sobre a extensão dos respectivos domínios na América do Sul.

A preparação da expedição de reconhecimento da rota do Madeira

Em 1748, preocupado com as notícias do avanço dos jesuítas espanhóis na margem oriental do rio Guaporé, Azevedo Coutinho reiterava ao governador do Maranhão os propósitos geoestratégicos do reconhecimento da rota do Madeira, já então admitindo a necessidade de se vir a permitir a comunicação entre o Mato Grosso e o Pará por aquele caminho:

Suposto o que deixo explicado tem-se por necessario, e conveniente naõ sô apossarmo-nos da navegaçaõ do Rio da Madeira athê o Mato grosso, maz tomar a tempo as medidas para que a dita nova Missaõ Espanholla noz naõ cauze os prejuizos, que podemos recear, ou procurando os meyos para a tirar daly, sem escandalo, ou rodeando-a em alguma distancia com abitaçoens, e sesmarias dos nossos, de sorte que se naõ possaõ os Castelhanos alargar, nem tentar outros estabelecimentos da parte oriental do Rio da Madeira, e talvez virá a ser Conveniente para este effeito permeti-se, e frequentar-se a comunicação do Pará com o Mato groço por aquelle Rio. [...] Porem como para se tomar huma ajustada resoluçaõ nesta materia, hê precizo precederem maduros exames, e exploraçoens; hê S. Magestade Servido, que V. S. escolha a peçoa mais prudente, e capaz que ahi achar, e comunicando-the
16. Parte das informações sobre a chegada de Manuel Félix de Lima a Belém e a sua estadia no Reino só se encontram em R. Southey (1981, p. 193-194). Ver também a Carta de João de Abreu Castelo Branco, de 24 de fevereiro de 1743 , acompanhada do auto de perguntas feitas aos sertanistas no AHU, Documentos do Pará, Cx. 25, D. 2387; e, ainda, a resposta de D. João V, redigida por Alexandre de Gusmão, em 17 de junho de 1744 , apud J. Cortesão (parte III, t. II, 19501963, p. 81-82). As citações ao texto desta obra, referemse à 2. ed., em quatro volumes, feita em Lisboa em 1984; as citações relativas aos apêndices documentais são relativas à 1 . ed., dividida em cinco partes e nove tomos, feita pelo Instituto Rio Branco, no Rio de Janeiro, entre 1950 e 1963. 
17. Cf. Marco Antonio Azevedo Coutinho (1987, p. 47).

18. Ver as instruções do governador do Maranhão em: Regimento que ha de observar o sargento-mor desta praça do Parâ Luiz Fagundez Machado na expedição de que hê cabo na forma que abaixo se declara; no AHU, Docs. Avulsos, Pará, 1750.

19. Ver, no mesmo Arquivo e seção: Instrução que ha de observar Joze Gonçalvez da Fonseca na expedição que por ordem de Sua Magestade mando fazer pelo Rio da Madeyra atê ao arrayal das $\mathrm{Mi}$ nas do Matto Grosso. Não parece possível que tivessem algum mapa do Amazonas feito pelo padre Cristobál de Acuña, cujo paradeiro se desconhece. Trata-se, muito provavelmente, de uma referência ao mapa do Amazonas do padre jesuíta Samuel Fritz, em sua versão impressa de 1707 . debaixo de segredo tudo o que the deixo referido, the encarregue o mando, e imcumbencia desta exploraçaõ ${ }^{17}$.

As instruções referiam que os objetivos da viagem de exploração eram secretos, devendo o responsável pela expedição seguir com alguns homens em canoas armadas para poder repelir qualquer ataque dos índios selvagens ou cristianizados. Depois de feitos os abastecimentos nas últimas aldeias dos jesuítas portugueses no rio Madeira, não deviam desembarcar em terra enquanto se encontrassem perto das missões de Moxos. Caberia ainda ao cabo fazer uma relação muito detalhada da viagem, devendo tomar nota de todo o tipo de informações relativa aos rios, ao relevo, à localização das povoações portuguesas e espanholas e ao seu número de habitantes. Da expedição devia ainda fazer parte alguém que pudesse calcular as coordenadas geográficas. Uma vez chegados ao Mato Grosso, deveriam recolher todas as informações possíveis sobre aquelas minas e as de Cuiabá, e sobre outros descobrimentos mais recentes, para além das informações sobre as missões espanholas.

Em julho de 1749, seguindo as ordens da coroa, Francisco Pedro de Mendonça Gorjão, governador do Estado do Maranhão e Grão-Pará, atribuiu ao sargento-mor Luís Fagundes Machado o comando da expedição, instruindo-o sobre os propósitos daquela navegação:

Empreenderá a viagem pello rio da Madeira dando lugar a que desde a boca athé ao Matto Grosso se façaõ os exames e observações pelo que leva a instrução necessária Jozê Gonsalves da Fonseca [...] e alguma materia que sobre este particular comferir o mesmo Jozê Gonçalves, e o piloto Antonio Nunes com o dito cabo, este concorrera com o seu parecer no que for conveniente para qualquer averiguação das que levaõ a seu cargo; pois todas as que houverem de fazer na forma da referida instrução são muy importantes ao serviço de Sua Magestade $^{18}$.

Cabia, portanto - a José Gonçalves da Fonseca, secretário do governo do Estado do Maranhão e Grão-Pará, e ao piloto António Nunes -, a realização de observações astronômicas. Como seria natural, o regimento dado pelo governador ao cabo tratava essencialmente de questões práticas ligadas à viagem e, principalmente, à segurança da expedição. Ao contrário, as instruções dadas a Fonseca centravam-se na recolha de informações durante a viagem, que devia apontar num diário; no cálculo das coordenadas geográficas; e na elaboração de mapas: "descreverâ o mesmo Amazonas em mapas, combinando as alturas, voltas e rios, com as que descrevem o mapa do padre Acunha, e Monsieur de La Condamine, em que seguirá o que achar mais exacto, segundo a conferencia que fizer com o piloto António Nunes, que será obrigado a fazer todas as observações necessarias em cada dia"19.

António Nunes deveria levar consigo "todos os instrumentos capazes de tomar as alturas e agulha de observar os rumos"; e era obrigado a fazer o seu próprio diário da viagem, onde deveria anotar os dias de navegação e as latitudes observadas. Já as instruções de Fonseca eram ainda mais precisas quanto 
ao que devia fazer a partir do momento em que a expedição entrasse no rio Madeira: esperava-se que tivesse um cuidado redobrado nas observações que fosse realizando, anotando os rumos da corrente do Madeira, o número de cachoeiras, as dificuldades em atravessá-las e as distâncias entre elas. A preocupação com o cálculo das latitudes era uma constante: todos os dias deviam tomar a altura do Sol, principalmente na boca dos rios. Para além de novos mapas do Amazonas, que antes referimos, deveria Fonseca desenhar um mapa do rio Madeira que mostrasse por onde se devia navegar e que permitisse visualizar as informações que fosse anotando sobre o rio e seus afluentes, e sobre as missões de Moxos. Uma vez chegado ao Mato Grosso, também the era pedido que fizesse um mapa onde registrasse todos os dados relativos à rede hidrográfica, ao relevo e às povoações portuguesas e espanholas, nomeadamente sobre Cuiabá e o caminho que ligava esta vila ao Mato Grosso ${ }^{20}$.

A viagem pelo rio Madeira

Sob o pretexto de conduzir de volta às Minas do Mato Grosso dois paulistas que tinham chegado ao Pará através dos rios Guaporé, Mamoré e Madeira, a expedição, comandada por Luís Fagundes Machado, partiu de Belém em julho de 174921. Após nove meses de viagem, chegaram ao Mato Grosso. $\bigcirc$ regresso foi mais rápido: tendo partido em setembro de 1750, chegaram a Belém três meses depois ${ }^{22}$.

Desta viagem resultaram vários documentos importantes de entre os quais a Derrota da Cidade de Belém do Grão-Pará até às minas do Mato Grosso, um roteiro da viagem escrito pelo piloto da expedição, António Nunes de Sousa, que contém uma narração sucinta da viagem, com a indicação dos rumos do rio Madeira e as latitudes da maior parte das bocas dos rios, das cachoeiras e das aldeias dos missionários ${ }^{23}$. Mas é o diário da viagem escrito por José Gonçalves da Fonseca que nos interessa aqui destacar. Trata-se da Navegação feita da cidade do Gram Pará até à bocca do Rio da Madeira pela escolta que por este rio subio às Minas do Mato Grosso por ordem mui recommendada de Sua Magestade Fidelissima no anno de 1749... ${ }^{24}$. Este diário compõe-se de três partes: a viagem desde o Pará até à boca do rio Madeira, a navegação do Madeira e a travessia das 19 cachoeiras deste rio e a subida do rio Guaporé até Mato Grosso. O diário da navegação é completado pela sua descrição das minas do Mato Grosso e Cuiabá, conhecido pelo título Notícia da Situação de Mato-Grosso e Cuyabá: Estado de Umas e Outras Minas e Novos Descobrimentos de Ouro e Diamantes ${ }^{25}$. Aos textos de Fonseca, deve acrescentar-se a Carta Hidrográfica, que deve tê-los acompanhado desde o início (Figura 1$)^{26}$.

A história do manuscrito de Fonseca ainda não está feita. Só em 1826 o diário da viagem propriamente dita foi publicado pela Academia das Ciências de Lisboa. Vários anos depois, em 1866, a Notícia da Situação de Mato-Grosso
20. Idem, ibidem.

21. Os dois paulistas eram José Leme do Prado e Francisco Xavier de Abreu, que tinham chegado ao Pará nos finais de 1748 ou início de 1749. Cf. carta do governador Francisco Pedro de Mendonça Gorjão de 22 de Abril de 1749 e o Regimento entregue pelo mesmo governador a Luiz Fagundes Machado relativo à expedição ao rio Madeira já citado anteriormente, ambos no AHU, Documentos Avulsos, Pará, 1750 .

22. Sobre a história desta expedição ver: M. J. Guedes e M. J Gomes (1992, p. 163 194); D. Davidson (1970, p. 61-62); I. Adonias (v.1, 1963, p. 499-500).

23. Ver Antonio Nunes de Souza (1906, p. 256-270).

24. Ver José Gonsalves da Fonseca (1826).

25.. Ver José Gonçalves da Fonseca (1866).

26. O título completo do mapa é: "Carta Hydrografica em que se descreve as origens de vários e grandes Rios da América Meridional Portugueza e muito especialmente o nascimento do Rio da Madeira e os rumos da sua direcção, com os rios que lhe saõ collatheraes, até entrar no famoso Rio das Amazonas observado tudo exactamente por ordem de Sua Magestade Fidelissima no anno de 1750 E da mesma sorte se faz publica a verdadeira origem do Rio Paraguay incognita a toda a Geografia antiga e moderna, descrevendose a confluencia de aguas que formaõ o tronco principal desse grande Rio, que com os maes foraõ delineados no Mato Grosso por José Gonçalves da Fonseca Explorador de toda esta indagação no mesmo anno". Dimensões: 143 $\mathrm{cm} \times 121,8 \mathrm{~cm}$. Mapoteca da Biblioteca da Marinha, Rio de Janeiro. 


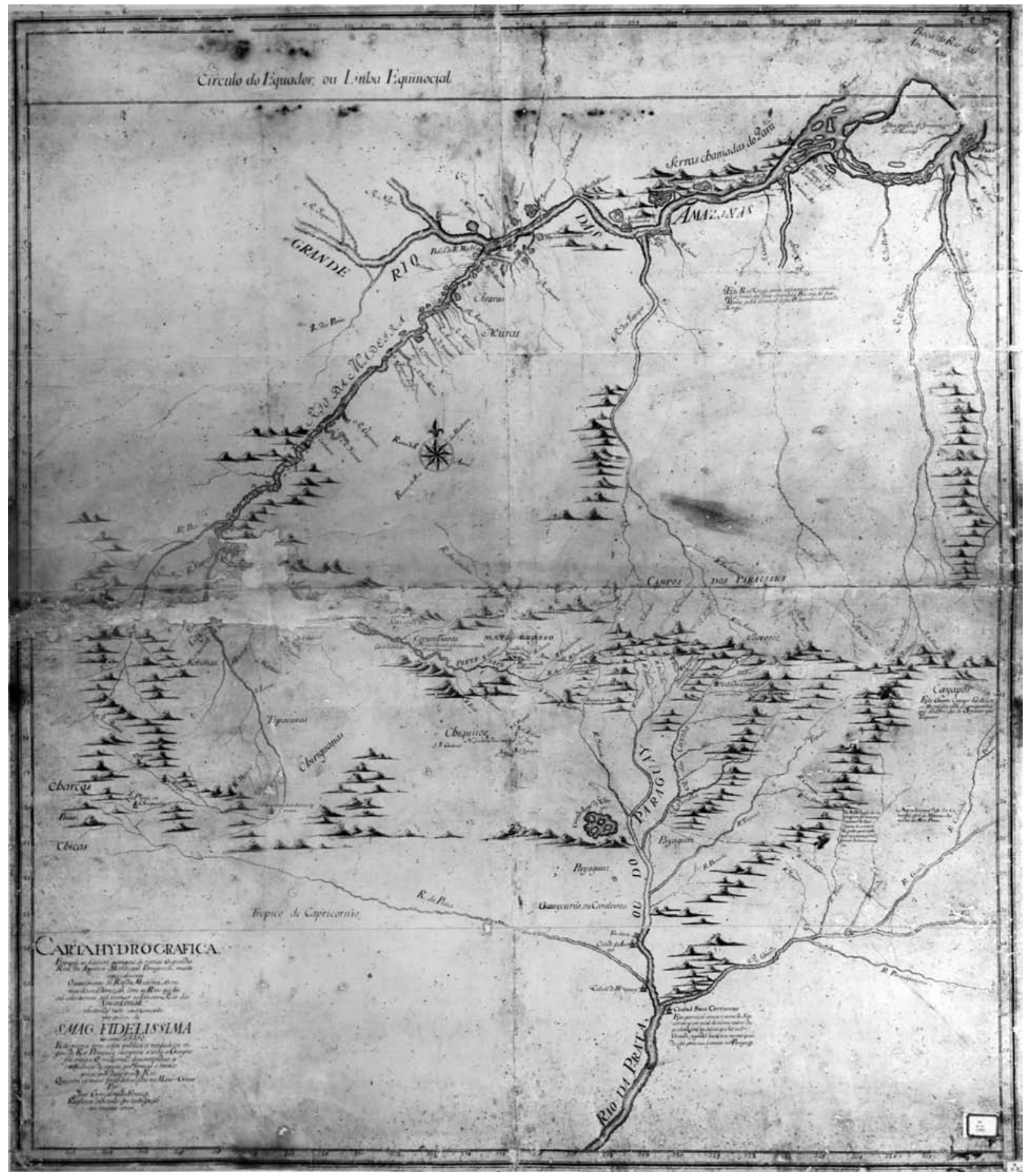

Figura 1- José Gonçalves da Fonseca. Carta Hydrografica em que se descreve as origens de vários e grandes Rios da América Meridional Portugueza e muito especialmente o nascimento do Rio da Madeira e os rumos da sua direcção. 1750. $143 \mathrm{~cm} \times 121,8 \mathrm{~cm}$. Mapoteca da Biblioteca da Marinha, Rio de Janeiro. 
e Cuyabá também foi publicada, na revista do Instituto Histórico e Geográfico Brasileiro. Se existem várias cópias manuscritas do diário de Fonseca e das "notícias" sobre o Mato Grosso, não sabemos onde se encontram os manuscritos originais, e só pelo cotejo das diferentes versões manuscritas existentes será possível proceder a uma edição crítica satisfatória ${ }^{27}$.

É interessante, então, saber que na Biblioteca Nacional do Rio de Janeiro, no final de um dos manuscritos da viagem de Fonseca lque corresponde apenas à navegação do Madeira até ao Mato Grosso), encontramos um pequeno mapa manuscrito, onde se pode ver representada a viagem de Fonseca até ao arraial de São Francisco Xavier ${ }^{28}$ (Figura 2). Existe um exemplar idêntico, mas colorido e de maiores dimensões no Arquivo Histórico Ultramarino, em Lisboa, que também não está assinado 29 (Figura 3).

Parecia, assim, num primeiro momento, que um destes mapas, ou o seu borrão, tivesse sido traçado por Fonseca ao longo da viagem ou na chegada ao Mato Grosso, e que precedesse a importante Carta Hidrográfica onde Fonseca incorpora, com outro cuidado e exatidão, as observações geográficas realizadas e as informações recolhidas nas minas do Mato Grosso (Figura 1). De fato, a corroborar tal idéia encontramos, em ambos os mapas, não apenas o traçado idêntico do curso dos rios Madeira, Mamoré e Guaporé, mas, ainda, das dezenove cachoeiras assinaladas no primeiro desses rios e os mesmos topônimos, ou quase. $\bigcirc$ fato de serem os outros dois mapas (Figuras 2 e 3) de menor escala - e, portanto, menos detalhados - podia fazer crer que se trata de mapas anteriores, ou preparados a partir de um mapa anterior à Carta Hidrográfica. Assim se explicaria que a grande novidade cartográfica deste mapa - ou seja, a figuração do nascimento dos rios Paraguai e Jauru, e sua separação da lagoa de Xarayes ou dos Xarayes (anteriormente tida como resultado da junção desses rios com o dos Porrudos e o de Cuiabá, de acordo com o Mapa das Cortes) - não se encontrasse nos outros mapas (Figuras 2 e 3) Aqui o desenho das origens do Paraguai é completamente diverso, e o rio Cuiabá surge como afluente dele e, além disso, com o rumo trocado, correndo de nordeste para sudoeste ${ }^{30}$.

Contudo, em nada implica a sua anterioridade o fato de serem os mapas das figuras 2 e 3 "menos exatos" que a Carta Hidrográfica. A única coisa que efetivamente sabemos é que estes mapas são posteriores à viagem de Fonseca e que, de certa forma, incorporam parte dos dados presentes na Carta Hidrográfica: o autor parece ter-se baseado nela para o traçado dos rumos dos rios Madeira, Guaporé e Mamoré. Assim, sua junção ao manuscrito da viagem de Fonseca pelo Madeira até ao Mato Grosso, longe de nos permitir atribuir a este último a sua autoria, servia apenas para a ilustração do percurso descrito no texto. $O$ fato de, graças ao sombreado patente no mapa anexo ao texto de Fonseca (que se encontra na Biblioteca Nacional do Rio de Janeiro), ser possível identificar o traçado da linha de fronteira de acordo com o Tratado de Madri, principalmente no que toca ao Solimões e ao Madeira-Guaporé, faz-nos pensar tratar-se de um mapa feito para servir de apoio aos demarcadores das partidas do Norte (Figura 2).
27. Nas cópias manuscritas do diário que se conhecem, falta a primeira parte - isto é, Navegação feita da Cidade do Gram Pará até à bocca do Rio da Madeira -, que consta da versão impressa pela Academia das Ciências. Três dessas cópias estão no Rio de Janeiro, na Secção de Manuscritos da Biblioteca Nacional. Em Lisboa, no AHU também se encontra uma cópia manuscrita do Diário (AHU, códice 1213 , fls. 63-188v.) e das Notícias sobre os arraiais de Mato-Grosso e sobre as Minas do mesmo nome e as do Cuiabá (AHU, códice 1213, fls.189-223).

28. O mapa mede $27,7 \mathrm{~cm} \mathrm{x}$ $28 \mathrm{~cm}$. Encontra-se no último fólio do manuscrito Navegação do Rio da Madeira, principiada em 25 de setembro de 1749 (Biblioteca Nacional, Rio de Janeiro, Divisão de Manuscritos, $\mathrm{n}^{\circ} 2,3,8$ ). Agradeço ao Dr. Carlos Francisco Moura o seu empenho na obtenção de um diapositivo deste mapa.

29. Trata-se do mapa 823 , pertencente à Cartografia Manuscrita do Brasil, do AHU. As dimensões do mapa são $28,8 \mathrm{~cm}$ x $29,9 \mathrm{~cm}$.

30. Sobre a história desse espaço ver o importante livro de M. F. Costa (1999). 


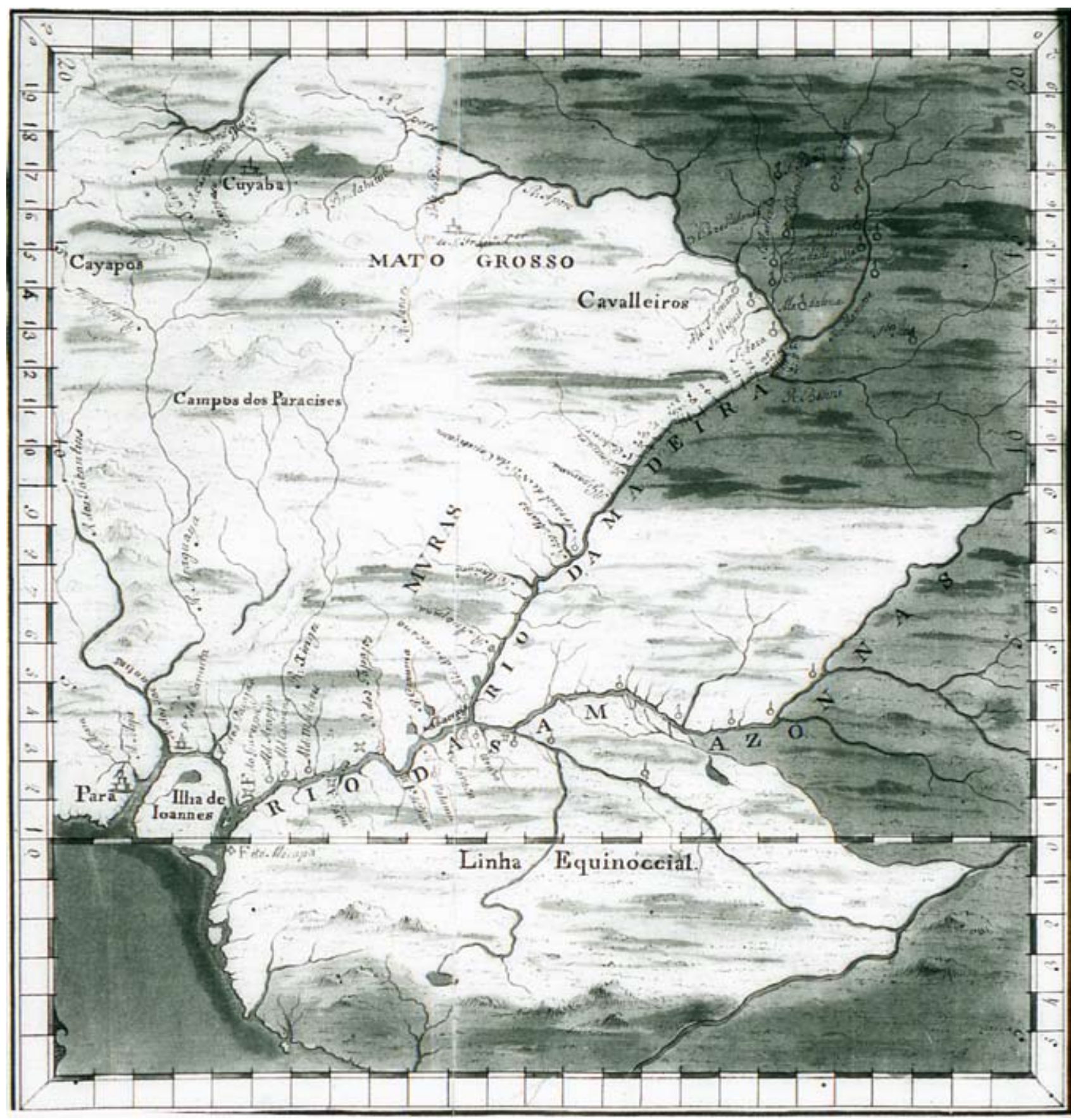

Figura 2 - Mapa da rota dos rios Madeira, Mamoré e Guaporé ligando Belém do Pará ao Mato Grosso. [ca. 1752]. $27,7 \mathrm{~cm} \times 28 \mathrm{~cm}$. Fundação Biblioteca Nacional, Rio de Janeiro. 


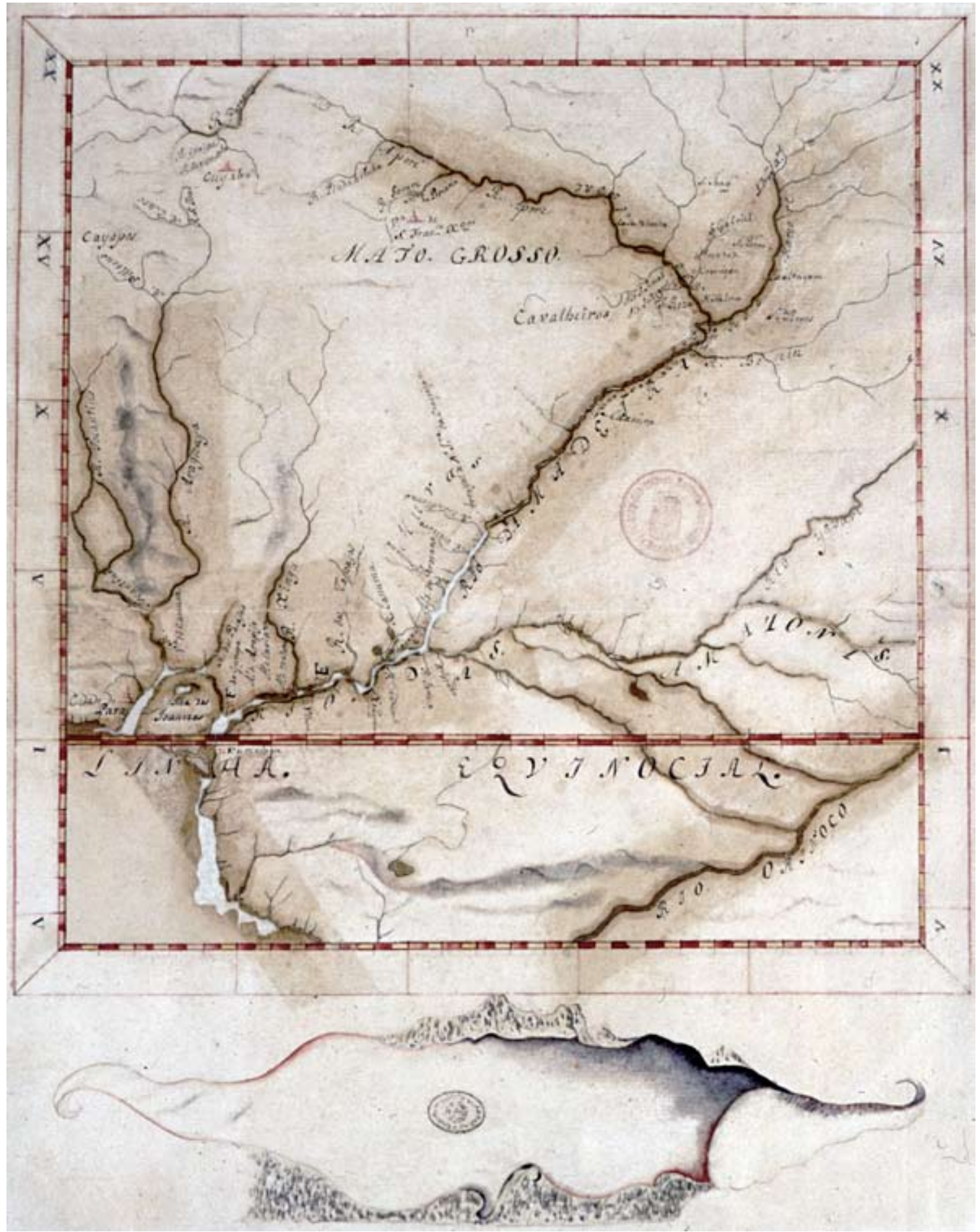

Figura 3 - Mapa da rota dos rios Madeira, Mamoré e Guaporé ligando Belém do Pará ao Mato Grosso. [ca. 1752]. 29,9 cm $\times 28,8 \mathrm{~cm}$ em folha de $38,2 \mathrm{~cm} \times 30 \mathrm{~cm}$. Cartografia Manuscrita do Brasil, n. 823. Arquivo Histórico Ultramarino, Lisboa. 
31. O Tratado das Instrucções dos Comissários da Parte do Norte só foi assinado em 24 de junho de 1752 e ratificado em 5 de julho do mesmo ano. Ver o texto deste tratado em A. C. F. Reis (v. 2, 1993, p. 170-180). Sobre as partidas do Norte ver: $\mathrm{J}$. Cortesão, (v. 4, 1984, p. 962 968); A. C. F. Reis (1993, p. 69-74); A. Domingues (1991, p. 28-40); e, ainda, C. F. Moura (2008).

32. Cf. José Antonio Fonseca (1866, p.389).

33. Idem, p.389-390.
Por fim, confirmando o seu desenho mais tardio, há uma designação toponímica que não se encontra nem na Carta Hidrográfica, nem no diário de Fonseca. O arraial de São Francisco Xavier, o mais importante núcleo populacional da chapada do Mato Grosso, surge nestes mapas (em qualquer das suas versões) com a designação de vila, assinalada com o respectivo símbolo (Figuras 2 e 3). Ora, o arraial naõ foi vila no tempo de Fonseca, nem imediatamente depois. A vila, capital da nova capitania de Mato Grosso, viria a ser fundada pelo governador D. António Rolim de Moura em março de 1752, com o nome de Vila Bela da Santíssima Trindade, no local de Pouso Alegre, na margem do rio Guaporé, e não no arraial de São Francisco Xavier. Contudo, nestes mapas, a designação, como vila, do arraial mais importante do Mato Grosso traduz, pensamos, a expectativa natural de que o futuro governador o elevasse a vila. Parece-nos, assim, que esse mapa deve datar de não antes de 1752 mas, provavelmente, já de 1753, quando as iniciativas das duas coroas relativas às partidas do Norte se tornaram mais efetivas ${ }^{31}$.

No final da sua Notícia da Situação de Mato-Grosso e Cuyabá, José Gonçalves da Fonseca não podia ser mais claro sobre o mapa que desenhou e os seus objetivos: "Para melhor percepção do que se contém no diario da navegação do rio da Madeira, a positura da chapada do Mato-Grosso, descrevi no presente mappa as partes essenciaes de todo o continente que viajei debaixo das graduações e rumos, que observou o piloto Antonio Nunes, e eu presenciei juntamente com o sargento-mór, commandante da escolta Luiz Fagundes Machado" 32 .

Ou seja, no mapa por ele traçado para acompanhar o diário da navegação pelo Madeira, procurou descrever tudo o que observou ao longo da viagem. Mas não ficou só nisso, recorrendo a informações obtidas no Mato Grosso para figurar o que não explorara,

e para que tambem mais facilmente se comprehendesse a direcção da cordilheira geral e rios, que d'ella nascem para o norte a buscar o Amazonas, e para o sul a formarem o Paraguay e outros, que n'elle desaguam: faço no mesmo mappa a configuração de tudo o que pode contribuir para uma completa noticia do continente, de toda a jurisdicção do Cuyabá e dominios hespanhoes confinantes com aquelles de sua Magestade Fidelissima, para que sendo $V$. Exa. servido o envie á real presença do mesmo senhor, com a certeza de que tudo o que nelle se contem e não foi do meu pessoal exame me regulei por informes de sujeitos fidedignos [...] pelos quaes achei concordarem as suas noticias com as que se acham nos mappas geraes, em que somente differem no nascimento do Paraguay, lago de Xarayes e nomes de alguns rios que por repetidas conferencias que fiz no Matto Grosso com pessoas que os tem navegado, achei ajustarem-se todas com o que relato n'esta informação e descrevi no referido mappa ${ }^{33}$.

Assim se confirma que, em seu mapa, Fonseca desenhou o nascimento do rio Paraguai e a lagoa de Xarayes de forma nova em relação aos mapas conhecidos até então (como representados na Carta Hidrográfica). Se as declarações de Fonseca não fossem suficientes, temos ainda outros dois 
documentos importantes a comprovar o fato: a carta do governador do Estado do Maranhão e Grão-Pará Francisco Pedro Mendonça Gorião ao Secretário de Estado Diogo de Mendonça Corte Real, de dezembro de 1751 ; e o parecer do bispo do Pará sobre a abertura da rota do Madeira, datado de janeiro do ano seguinte. Em sua carta, Mendonça Gorião pretende dar conta dos resultados da viagem ao Mato Grosso, comandada pelo sargento-mor Luiz Fagundes Machado, em que coubera a José Gonçalves da Fonseca a "diligência da exploração", pois - governador o considerava relativamente instruído "nas materias de Geografia, e com propensão para indagar as que fossem precizas". Após fazer um resumo do diário da viagem e das notícias recolhidas no Mato Grosso, Mendonça Gorião afirma:

Para mais cabal compreensão de todas as notícias, que o referido José Gonçalves descreve no Diário de sua derrota, e pelas que adquiriu no Mato Grosso, de que fez a coleção mencionada, delineou na mesma chapada um mapa graduado, em que lançou o rio da Madeira, segundo os rumos de sua navegação, e dá uma exata, e nova noticia do verdadeiro nascimento do Paraguay; [...] o qual mapa juntou à sua escrita e com ela o enviou a V. $\mathrm{Exa}^{34}$.

testemunho do bispo do Pará é quase idêntico ao do governador. Em seu parecer sobre a abertura da rota do Madeira, refere-se a Fonseca como "o primeiro explorador do Rio da Madeira" e menciona o diário da exploração, ao qual o antigo secretário do Governo do Estado do Maranhão e Grão-Pará acrescentara

huma colleção das notícias mais importantes que pode adquerir, regulando-se pelos informes de pessoas de credito e experiencia naquelles a que era impossivel chegar o seu pessoal exame, coroando todo este trabalho com hum Mapa particular da Chapada do Matto Grosso, e com huma Carta Geografica de toda a derrota pelo Rio Madeira, em que novamente descobre a origem do famoso Nilo da America, como até agora se podia intitular o grande Rio Paraguay ${ }^{35}$.

Do mapa da chapada do Mato Grosso, a que Fonseca se refere no texto da Notícia como "planta da Chapada", não se conhece o paradeiro ${ }^{36}$. Mas a carta geográfica mencionada pelo bispo é, mais uma vez, a mesma que contém a viagem pelo rio Madeira e o desenho do nascimento do rio Paraguai. Ou seja, novamente se trata da Carta Hidrográfica, não há referência a outros mapas.

Por fim, para além dos argumentos já aduzidos, outros elementos há que corroboram a tese de que Fonseca terá traçado apenas a Carta Hidrográfica e, dela, terá feito cópias. Estes dados se encontram na correspondência trocada entre Sebastião José de Carvalho e Melo, então secretário de Estado dos Negócios Estrangeiros, e seu irmão Francisco Xavier de Mendonça Furtado, desde 1752 o principal comissário das partidas de demarcação do norte e, desde o ano anterior, governador do Estado do Grão-Pará e Maranhão lassim renomeado a partir de
34. Carta de Mendonça Gorjão, de 1 de dezembro de 1751; apud A. C. F. Reis (1993, p. 144).

35. Ver idem, p. 152, a Carta do bispo do Pará, frei Miguel de Bulhões, de 12 de Janeiro de 1752 .

36. Cf. José Antonio Fonseca (1866, p. 361).

Annals of Museu Paulista. v. 17. n.2. July - Dec. 2009. 
37. Ver o texto do Tratado de Limites. Apud J. Cortesão (v. IV, 1984, p. 918-929)

38. Carta de Alexandre de Gusmão a Tomás da Silva Teles, de 8 de fevereiro de 1749. Idem, p. 871.
1751, dada a maior importância do Grão-Pará). Mas tal correspondência revela sobretudo a importância, no período posterior à assinatura do Tratado de Madri, da viagem de Fonseca (e do seu mapa) no pensamento dos ministros portugueses, precisamente por demonstrar ser problemática a demarcação da linha de fronteira, na região ao sul do Mato Grosso, tal como ela fora acordada no tratado. No que toca à representação desse espaço e ao traçado do curso dos rios que nele se encontram, a contradição entre o mapa de Fonseca e o Mapa das Cortes não podia ser maior.

A Carta Hidrográfica, de José Gonçalves da Fonseca, e as demarcações do norte

Como é sabido, em janeiro de 1750, ao ser assinado em Madri o tratado de limites entre as duas coroas ibéricas, em Lisboa ainda se desconheciam os resultados da expedição de Fonseca. Daí que seja bastante vago o artigo VII do tratado, relativo às demarcações a realizar no território situado entre os rios Jauru e Guaporé. Para o que agora nos interessa, basta dizer que a linha de demarcação corria desde o rio mais próximo do lgurey (afluente do Paraná), que se supunha ser o Corrientes, que desaguava no Paraguai pela sua margem oriental e subia depois ao longo do Paraguai até à extensa área pantanosa conhecida por lagoa de Xarayes, e daqui até à boca do rio Jauru. Daqui deveria seguir em linha reta até à margem do sul do rio Guaporé, em frente da boca do rio Sararé, e depois ao longo do curso dos rios Guaporé, Mamoré e Madeira até alcançar neste rio um ponto equidistante da confluência do Madeira com o Amazonas e da boca do Mamoré. Contudo, no mesmo artigo se determinava que, se os comissários das duas coroas que deveriam regular os limites, em chegando àquele território, encontrassem

entre os rios Jaurú e Guaporé outros rios ou balizas naturais, por onde mais comodamente, e com maior certeza se possa assinalar a Raia naquela paragem, salvando sempre a navegação do Jauru que deve ser privativa dos Portugueses, e o caminho que eles costumam fazer do Cuiabá para o Mato grosso [...] que assim se estabeleça, sem atender a alguma porção mais ou menos de terreno, que possa ficar a uma ou a outra parte ${ }^{37}$.

Já cerca de um ano antes, quando do envio do Mapa das Cortes a Tomás da Silva Teles, embaixador português em Madri, Alexandre de Gusmão afirmava, referindo-se ao mapa, que "o que medeia entre o rio Amazonas e a província dos Charcas é ideal e sem mais fundamento que saber-se que os rios grandes que desaguam no Amazonas vêm daquela parte" ${ }^{\prime 3}$. $O$ desconhecimento detalhado daquele espaço e a consequente impossibilidade de o representar cartograficamente de uma forma mais exata era, assim, um fato. Deste modo se 
explicava também a ressalva existente no artigo VII do tratado, de modo a permitir alguma liberdade aos demarcadores em face de um melhor conhecimento do terreno por onde devia passar a linha de fronteira.

Afastado Gusmão da direção do processo para a implementação do tratado - o que terá acontecido somente nos últimos meses de 1751 - e apesar de Sebastião José de Carvalho e Melo, o novo secretário de Estado dos Negócios Estrangeiros, ter-se manifestado contrário ao acordado em Madri, o tratado não foi, ainda assim, denunciado. No entanto, dada a animosidade existente entre os dois ministros, muito pouco das sutilezas que presidiram às negociações do Tratado de Madri - ou até várias informações importantes, nomeadamente relativas à forma como fora feito o Mapa das Cortes - deve ter passado de um ministro para o outro. Só assim podemos entender que alguns anos depois, em 1753, preocupado com a execução das demarcações no norte da América do Sul, o futuro marquês de Pombal estivesse extremamente embaraçado com as contradições existentes entre o Mapa das Cortes e a Carta Hidrográfica, de José Gonçalves da Fonseca. $\bigcirc$ problema colocava-se exatamente na dificuldade em delinear, face aos novos dados sobre o território compreendido entre o Mato Grosso e o Paraguai trazidos pelo mapa e pelos escritos de Fonseca, a linha de demarcação, de acordo com o tratado.

Em carta datada de 10 de maio de 1753, dirigida a seu irmão Francisco Xavier de Mendonça Furtado, governador do Grão-Pará e Maranhão, Carvalho e Melo mostrava-se bastante apreensivo sobre a implementação do tratado no terreno: "Observando-se porem a outra grande carta, que se fes na viagem de Jose Gonçalves da Fonseca se manifesta por ella que se o Rio dos Porrudos, o Rio Paraguay, o Rio Jahuru e Lagoa dos Xaraes correm e jazem nos lugares e na figura em que os descreveram daqui podem surgir grandes dificuldades"39.

Confrontando o mapa desenhado por Fonseca com o "Mapa das Cortes", Carvalho e Melo prosseguia, chamando a atenção para o problema principal, a saber, a proximidade excessiva de que os espanhóis ficavam do caminho entre Cuiabá e o Mato Grosso:

Porque tomando-se por extremidade Oriental a foz ou boca do Jauru e por extremidade ocidental a llha Comprida ou ainda a casa redonda, se não pode lançar a linha que esta descripta na carta concordada [o Mapa das Cortes] sem que ou por huma parte, ainda curvandose alguma coisa contra os dominios de Sua Magestade e deixando para a parte de Hespanha toda a Lagoa dos Xaraes, comprehendendo o Territorio das aldeias hespanholas que ficam a Ocidente do mesmo Jauru, ou pela outra parte, não só deixamos aos Hespanhoes aberta a foz do rio dos Porrudos e por consequência o rio Cuyabá para comunicarem por ele com as nossas minas que estão nas suas cabeceiras, mas taobem mettamos os mesmos Hespanhoes dentro em nossa casa, chegandollos demasiadamente ao caminho que vae do Cuyabá para Mato Grosso 40 .

A preocupação de Carvalho e Melo não era nova. Já numa carta anterior, o futuro marquês de Pombal lembrava a Mendonça Furtado as dificuldades no traçado da linha de demarcação naquele território: "Na segunda [linha] que
39. Carta de Sebastião José de Carvalho e Melo a Francisco Xavier de Mendonça Furtado, de 10 de Maio de 1753 Apud J. A. Fonseca (1995, p. 291).

40. Idem, ibidem. 
41. Idem, ibidem.

42. Carta de Sebastião José de Carvalho e Melo a Francisco Xavier de Mendonça Furtado, de 6 julho de 1752 . Idem, p. 288.

43. Carta de Sebastião José de Carvalho e Melo a Francisco Xavier de Mendonça Furtado. de 10 de Maio de 1753. Idem, p. 291.

44. Idem, p. 292 corta do Rio Aporé ou lthenes á fox do Jahuru he necessario grande cuidado em a principiar a descrever o mais a Oeste que for possivel; porque se não houver essa prevenção pode isso ter a consequencia de ficarem os Hespanhoes entre o Mato Grosso e o Cuyabá, e Nós por elles cortados para a comunicação"41.

Este risco só poderia ser evitado se os comissários se ativessem à letra do artigo VII do tratado de limites, devendo a linha principiar no Guaporé o mais a sudeste possível "para se cortar dahi á boca ou fox do Jahuru; logo se evitará que fique pertencendo a Hespanha o territorio que jaz entre o Cuyabá e o Matto Grosso" 42 . Voltando à carta de maio de 1753, ali Carvalho e Melo manifestava a esperança de que ambos os mapas (o Mapa das Cortes e a Carta Hidrográfica) estivessem errados e de que um cuidadoso exame daquele território - e exortava o irmão a isso - permitisse perceber melhor a questão, lembrando-the ser de recear que os espanhóis, que ali estavam melhor estabelecidos, conhecessem melhor a região, com os inconvenientes que isso podia trazer para a demarcação da linha. Propunha-he, assim, que mandasse o quanto antes "tirar duas Cartas topographicas do Territorio em que se ha de descrever a Linha"43.

Entre os dois mapas, havia outras diferenças que colocavam problemas idênticos. A primeira radicava no fato de Fonseca colocar a foz do Japurá muito mais para Oriente do que se podia observar no Mapa das Cortes e, portanto, de forma contrária aos interesses portugueses, a quem interessava que a confluência do Japurá com o Amazonas, por onde passava a linha de demarcação, ficasse - mais possível para Ocidente. A segunda, prendia-se com as diferenças de latitude da foz do Mamoré nas duas cartas geográficas, e a distância entre esse ponto e a confluência do Madeira com o Amazonas, ficando assim os espanhóis demasiado próximos das missões portuguesas na margem sul do Amazonas, caso o mapa de Fonseca estivesse mais próximo da verdade. No final da carta, Carvalho e Melo escrevia ao irmão sobre a remessa do mapa e dos escritos de Fonseca:

Para melhor informação vossa e maior clareza de tudo o que deixo referido, ajunttarei a esta carta o Mappa, que se delineou [... .] na viagem de Joze Gonçalves da Fonseca, o qual contem a navegação que elle fes, desde essa Capital athe o Matto Grosso. Tãobem vão juntas as quattro rellações que o sobredicto escreveo, explicando os sucessos da mesma navegação, e a carta em que a recopillou o Governador Francisco Pedro de Mendonça Gorião44.

Sabemos, portanto, que Mendonça Furtado recebeu os textos e uma cópia do mapa de Fonseca. Até porque, um ano mais tarde, dirigindo-se a D. António Rolim de Moura, também ele faz uma comparação entre o Mapa das Cortes e a Carta Hidrográfica. Mais uma vez, seria o problema da disparidade na figuração da lagoa de Xarayes e do curso dos rios Paraguai e Jauru a chamar a sua atenção:

No dito Mapa pos o mesmo Fonceca a boca do Jahuru em vinte graus e meyo da parte do Sul, fazendo barra no Rio Paraguay, e já se vê a differença que faz ao Mapa das Cortes, 
que the demonstra a barra em catorze graus de Latitude dezaguando na Lagoa Xaraies, cuja diversidade me poem em grandissima duvida, porque a verdade deve ser hua para nella se estabelecerem as negociações e ver a vantagem que podemos tirar nellas ${ }^{45}$.

E continuava, estranhando o fato de, no Mapa das Cortes "dezaguarem" na lagoa de Xarayes dois rios Jaurú e dois rios Paraguai, enquanto no mapa de Fonseca não só a lagoa ficava a oeste do Paraguai, como não recebia nenhuma água desses rios, o que, dizia, consistia numa "diversidade total, e por isso se não pode formar juizo certo, fazendo combinaçoez com os ditos Mapaz" 46 .

Mendonça Furtado muito provavelmente ignorava como fora feito o Mapa das Cortes e que, principalmente no que respeitava ao território em causa, não tinha qualquer pretensão à exatidão. Só assim se explicariam as ressalvas sobre o traçado da linha de demarcação que constam do artigo VII do Tratado de Madri, a que já aludimos antes. Em todo o caso, o governador do Estado do Grão-Pará e Maranhão não se conformava com as contradições que resultavam do confronto dos dois mapas. Daí solicitar a Rolim de Moura que the remetesse, logo que possível, "hum Mapa claro, e distincto com os nomes que hoje tem estas Montanhas e Ryos para que não houvesse equivocação alguma" 47 que pudesse prejudicar os interesses da coroa portuguesa nas demarcações de limites que se anteviam.

Mendonça Furtado não tinha muita confiança em Fonseca, o que provavelmente influenciava a sua leitura da Carta Hidrográfica. Logo em janeiro de 1752, ao dar o seu parecer sobre a abertura da rota do Madeira, refere também que ouviu José Gonçalves da Fonseca a respeito do Tratado de Limites, ainda que tivesse "boas razões para entender que este homem não pode ter crédito nesta matéria". Desqualifica a opinião de Fonseca como "um arrazoado a favor da divisão" feito sem qualquer fundamento credível, tendo Fonseca cometido o erro de, em sua opinião, considerar boa a troca a da Colônia do Sacramento e seu território pelas terras que se recebiam no norte. Se é certo que Fonseca provavelmente não tinha a noção de que o equivalente recebido pela Colônia fora o Território dos Sete Povos das Missões, a verdade é que a opinião de Mendonça Furtado parece excessivamente negativa: "Como o ouvi discorrer com este fundamento, me dei por instruído das notícias do tal José Gonçalves, que não é destituído de préstimos, mas era preciso que tivesse o coração mais puro do que na verdade tem". Ao contrário, parecia ter em melhor conta João de Souza Azevedo, grande conhecedor dos sertões entre o Pará e o Mato Grosso e grande crítico do Tratado de Madri ${ }^{48}$.

Talvez assim se possa explicar o seu entendimento de que a Carta Hidrográfica fora, no essencial, desenhada por João de Souza Azevedo, e depois acrescentada por Fonseca, o que não encontra qualquer confirmação em nenhuma outra fonte e faz pensar na estratégia de Azevedo para se apropriar, em parte, dos resultados da missão de Fonseca, em benefício próprio, nos anos posteriores ao regresso da escolta ao Pará, sobrevalorizando o seu papel no bom sucesso da expedição. A confirmar tal tese está a afirmação de João de Souza Azevedo
45. Carta de Francisco Xavier de Mendonça Furtado a D. António Rolim de Moura, 28 de Maio de 1754. Apud J. Cortesão (parte 5, 19501963, p. 214).

46. Idem, ibidem.

47. Idem, ibidem.

48. Ver João de Souza Azevedo (1943). O parecer aí publicado encontra-se no AHU, códice 1213, fls.268-289 e, também, numa versão mais curta, com data de 26 de Janeiro de 1752 , nos fls. 234 239 do mesmo códice. Há reprodução em A. C. F. Reis (1993, p. 166-169). 
49. Ver a Petição de João de Sousa Azevedo ao Rei. AHU, Documentos Avulsos, Mato Grosso, 1751.

50. Ver, a carta de Francisco Pedro de Mendonça Gorjão ao secretário de Estado Pedro da Mota e Silva, de 10 de setembro de 1750 . AHU, Documentos Avulsos, Pará, 1750 .

51. No mesmo Arquivo e seção, ver a carta do governador Francisco Pedro de Mendonça Gorjão ao Rei, de 22 de Abril de 1749.

52. Carta de Francisco Xavier de Mendonça Furtado a D. António Rolim de Moura, 28 de Maio de 1754. Apud J. Cortesão (parte 5, 19501963, p. 214). de que a escolta de Luiz Fagundes Machado o teria encontrado regressando do Mato Grosso, na fortaleza dos Pauxizes, tendo ele "vencido já a maior parte do caminho" e que aí teria recebido ordem para retroceder e acompanhar a tropa, para the ensinar o caminho até ao Mato Grosso, ao que "promptamente obedeceo, conduzindo os athe as ditas Minas do Mato Grosso; exprementou trabalhos, e adquerio achaques, perdendo dous dedos de huã maõ por vencer as deficuldades" e "por astucia do supplicante se venceraõ passagens por cachoeiras de caudelozos rios, ficando sem deficuldade a comunicação e navegação" até ao Mato Grosso ${ }^{49}$. Em vão se há de procurar traços dessas atividades tão importantes de Azevedo nos escritos de Fonseca. Mas se este dado não fosse suficiente, temos outras informações sobre o seu papel junto da expedição comandada por Luís Fagundes: a escolta encontrou João de Souza Azevedo em finais de novembro de 1749, no arraial de Nossa Senhora da Conceição, situado na margem direita do rio Madeira. E porque a rota do Madeira não estava aberta à navegação, Azevedo foi intimado a regressar ao Mato Grosso. Mas como muitos escravos tinham adoecido ao chegar junto das cachoeiras do rio, e dada a falta de mantimentos, foi-he dada licença para ficar ali "enquanto se restabeleciaõ totalmente os servos que o remavão", e dali ele decidiu, em maio de 1750, a viajar até o Pará, onde entregou ao governador as cartas que levava dos moradores do Mato Grosso para o Rei ${ }^{50}$. Em resumo: não é impossível que Azevedo tenha ajudado a escolta, ou que esta se tenha beneficiado do auxílio dos seus escravos, mas é exagero pensar que seu papel na expedição tenha sido mais do que uma ajuda episódica. Nem mesmo como guia ele teria sido utilizado, até porque fora José Leme do Prado, um dos paulistas que fazia parte da escolta, a revelar a Azevedo, em finais de 1748, a rota do Madeira $^{51}$.

Na carta enviada a Rolim de Moura, Mendonça Furtado afirma então que Fonseca "juntou ao rustico Mapa que tinha feyto o tal Sousa, as noticias que poude achar quando esteve nas Minnaz, e no decurso desta larga viagem; e depois que assim combinou tudo, delineou hum mapa bastantemente claro". Contudo, ainda acreditando que, no que tocava à parte por ele explorada, estivesse perto da verdade (ou seja, no caminho do Pará ao Mato Grosso), afirmava Mendonça Furtado:

como elle não passou de entrar pelo Rio Sararê e delle passar aos Arrayaez de Sam Francisco Xavier, e Santa Anna, tudo o mais que delineou no dito Mapa foy por informaçõez que the derão, e como não sey se os informantes the participarão as exactas noticias, que eram precisaz para o formar com verdade [ao mapa], nesta justa desconfiança tambem não posso com pé seguro fiarme delle para a conclusão do negocio que devo $\operatorname{tratar}^{52}$.

Ou seja, da Carta Hidrográfica, só aceitava a validade do traçado da rota do Madeira-Guaporé. Considerava ser duvidoso tudo o mais, pois desconhecia se os informadores de Fonseca eram fidedignos. Se era legítimo ele questionar as fontes do mapa de Fonseca, a verdade é que até aí nenhuma outra 
expedição portuguesa se aproximara tanto do conhecimento daquele espaço, e não havia, de fato, qualquer outro mapa que fosse mais preciso do que aquele traçado por Fonseca, por muitos erros que ainda apresentasse ${ }^{53}$.

\section{Conclusões}

A primeira consequência da viagem de Fonseca foi, sem qualquer dúvida, a decisão régia de autorizar a abertura da rota do Madeira à navegação. Esta teve lugar em 23 de outubro de 1752. Pouco tempo depois, em 14 de novembro de 1752, o rei enviava uma provisão aos governadores do Mato Grosso e do Estado do Grão-Pará e Maranhão, informando-os da decisão de permitir a navegação e o comércio ao longo dos rios Madeira, Mamoré e Guaporé. Na segunda metade do seculo XVIII, essa rota viria a adquirir uma importância comercial não negligenciável. Mas seu valor era essencialmente estratégico: defender a fronteira do extremo-oeste brasileiro ${ }^{54}$.

Contudo, a viagem da "Real Escolta" pelo rio Madeira teve outras consequências importantes, graças, sobretudo, aos textos de José Gonçalves da Fonseca sobre a viagem e ao mapa que traçou para ilustrá-la. Trata-se do debate em torno do problema das demarcações de limites na fronteira da nova capitania do Mato-Grosso. As disparidades encontradas entre o Mapa das Cortes e a Carta Hidrográfica, de Fonseca, não podiam deixar de preocupar os ministros da coroa portuguesa e os governadores do Mato-Grosso e do Estado do Grão-Pará e Maranhão. Daí ser muito provável que o mapa da rota do Madeira tivesse por objetivo, em suas diferentes versões (Figuras 2 e 3), realizar uma síntese cartográfica quase impossivel entre o Mapa das Cortes e a Carta Hidrográfica, aceitando desta a figuração da rota Madeira-Mamoré-Guaporé, mas excluindo as novidades que apresentava relativamente aos cursos dos rios Cuiabá, Porrudos, Paraguai e Jauru, e à lagoa de Xarayes. Longe de diminuir a importância do mapa de Fonseca, esses mapas vários são a prova da sua influência na cartografia posterior e, principalmente, nas demarcações de limites do Norte, demonstrando o papel essencial da Carta Hidrográfica no complexo processo de definição da linha demarcadora no extremo-oeste do Brasil.

\section{REFERÊNCIAS}

ADONIAS, I. Mapas e planos manuscritos relativos ao Brasil colonial: 1500-1822. Brasília: Ministério das Relações Exteriores, 1960. 2 v.

A cartografia da Região Amazônica, v.1. Rio de Janeiro: Conselho Nacional de Pesquisas-Instituto Nacional de Pesquisas da Amazônia, 1963.
53. Sobre os erros do mapa de Fonseca, ver M. J. Guedes e M. J. Gomes (1992, p. 178$185)$.

54. Cf. D. Davidson (1973, p. 102-106). Sobre a cartografia portuguesa da região amazônica em geral - e, em particular, do Mato-Grosso - durante a segunda metade do século XVIII, ver: I. Adonias (1963); R. M. de Araújo (2000); J. C. Garcia (2002) 
Mapa: imagens da formação territorial brasileira. Rio de Janeiro: Fundação Emilio Odebrecht, 1993.

ABREU, C. de. Capítulos de história colonial e os caminhos antigos e o povoamento do Brasil. Brasília: Editora Universidade de Brasília, 1982.

ANAIS da Biblioteca Nacional do Rio de Janeiro, Rio de Janeiro, v. 23, 1901; v. 107, 1987.

ARAÚJO, R. M. de. A urbanização do Mato Grosso no século XVIII. 2000. Tese (Doutorado em História da Arte) - Faculdade de Ciências Sociais e Humanas da Universidade Nova de Lisboa, Lisboa, 2000.

AZEVEDO, J. S. Parecer [sobre o Tratado de Madrid, 16 de Janeiro de 1752]. Revista do Instituto Histórico e Geográfico Brasileiro, Rio de Janeiro, v. 179, p.183-207, 1943.

BLOCK, D. Mission culture on the Upper Amazon. Native tradition, Jesuit enterprise \& secular policy in Moxos, 1660-1880. Lincoln: University of Nebraska Press, 1994.

CORTESÃO, J. Alexandre de Gusmão e o Tratado de Madrid. Rio de Janeiro: Instituto Rio Branco, 1950-1963. [5 Partes, 9 Tomos]

Alexandre de Gusmão e o Tratado de Madrid. 2. ed. Lisboa: Horizonte, 1984. 4 v.

COSTA, M. F. História de um país inexistente. O Pantanal entre os séculos XVI e XVIII. São Paulo: Estação Liberdade/ Kosmos, 1999.

COUTinho, M. A. A. Carta do Secretário de Estado Marco Antonio de Az. ${ }^{\text {do }}$ Coutt. ${ }^{\circ}$ [a Francisco Pedro de Mendonça Gorjão, governador do Maranhão. 15 de setembro de 1748]. Anais da Biblioteca Nacional, Rio de Janeiro, v. 107, p. 45-48, 1987.

DAVIDSON, D. Rivers and empire: the Madeira route and the incorporation of the Brazilian far West, 1737-1808. New Haven: Yale University Press, 1970.

How the Brasilian West was won: freelance \& state on the Mato Grosso frontier, 1737-1752. In: ALDEN, D. (Ed.). Colonial roots of modern Brazil. Berkeley: University of California Press, 1973.

DOMINGUES, A. Viagens de exploração geográfica na Amazónia em finais do Século XVIII: política, ciência e aventura. Funchal: Região Autónoma da Madeira; Lisboa: Instituto de Historia de Além-Mar da Universidade Nova de Lisboa, 1991.

FONSECA, J. A. A propósito do Tratado de Limites a Norte do Brasil: cartas secretas de Sebastião José de Carvalho e Melo, 1752-1756. Mare Liberum, Lisboa, n.10, p. 291, dez. 1995.

FONSECA, J. G. da Navegação feita da cidade do Gram Pará até à bocca do Rio da Madeira pela escolta que por este rio subio às Minas do Mato Grosso por ordem mui recommendada de Sua Magestade Fidelissima no anno de 1749, escripta por Jose Gonsalves da Fonseca no mesmo anno [1749]. Collecção de noticias para a bistoria e geografia das nações ultramarinas, que vivem nos dominios portuguezes, ou lhe são vizinhas, Lisboa, v. 4, n. 1, 1826. [Academia Real das Sciencias]

Notícia da Situação de Mato-Grosso e Cuyabá: Estado de Umas e Outras Minas e Novos Descobrimentos de Ouro e Diamantes. Revista do Instituto Histórico e Geográfico Brasileiro, Rio de Janeiro, v. 29, p. 352-390, 1866. 
GARCIA, J. C. (Coord.). A mais dilatada vista do mundo: inventário da colecção cartográfica da Casa da Ínsua. Lisboa: Comissão Nacional para as Comemorações dos Descobrimentos Portugueses, 2002.

GUEDES, M. J.; GOMES, M. J. Primórdios da exploração do rio Madeira: a "escolta" do sargento-mor Luís Fagundes Machado e a carta hidrográfica de José Gonçalves da Fonseca. Anais Hidrográficos, Rio de Janeiro, v. 49, Suplemento, p. 163-194, 1992.

MAGAlHÃES, J. A. R. de. Um novo método de governo: Francisco Xavier de Mendonça Furtado, governador e capitão-general do Grão-Pará e Maranhão (1751-1759). Revista do Instituto Histórico e Geográfico Brasileiro, Rio de Janeiro, v. 165, n. 424, p.183-207, jul.-set. 2004.

MOURA, C. F. Astronomia na Amazônia no século XVIII [Tratado de Madri]: os astrônomos Szentmártonyi e Brunelli - instrumentos astronômicos e livros científicos. Rio de Janeiro: Real Gabinete Português de Leitura, 2008.

PRADO, F. L.. Verdadeira noticia que deo Francisco Leme do Prado do que passou, vio, e experimentou na Viagem que fez destar Minas do Matto groço pelo Rio abaixo as Missoens dos Padrez da Companhia do Reyno de Castela, a que chamaõ Moxos, cujas pertencem a Provincia da Cidade de Lima, Hindo por companheiros. Manoel Feliz Lima, Joaquim Ferreira Chaves, Vicente Pereira da Ass_pçam, Manoel de Freitas Machado, Matheos Correa Leme, Joam dos Santos Berneque: paragens por onde naõ Consta andasse pessoa Portuguesa. Anais da Biblioteca Nacional, Rio de Janeiro, v. 107, p. 49-55, 1987.

REIS, A. C. F. Limites e demarcações na Amazônia Brasileira. Belém: Secult, 1993, 2v.

REVISTA DO INSTITUTO HISTÓRICO E GEOGRÁFICO BRASILEIRO. Rio de Janeiro, v. 29, 1866; v. 67,1906 ; v. $179,1943$.

SÁ, J. B. de. Relação das povoaçoens de Cuyabá e Mato Grosso (1775). Anais da Biblioteca Nacional, Rio de Janeiro, v. 23, p. 5-58, 1901.

SOUTHEY, R. Historia do Brasil, v.3. Belo Horizonte: Itatiaia, 1981.

SOUZA, A. N. Derrota desta cidade de Santa Maria de Belém do Grão Pará para as Minas de Mato Grosso [parte 1]. Revista do Instituto Histórico e Geográfico Brasileiro, Rio de Janeiro, v.67, p. 256-270, 1906.

Artigo apresentado em 8/2008. Aprovado em 3/2009.

Annals of Museu Paulista. v. 17. n.2. July - Dec. 2009. 